\title{
Hubungan Kadar Hemoglobin dengan Laju Filtrasi Glomerulus pada Pasien Penyakit Ginjal Kronik Stadium 3 dan 4 Di RSUP Prof. Dr. R. D. Kandou Manado Periode Januari 2017 - Desember 2018
}

\author{
Fabio M. Patrick, ${ }^{1}$ Octavianus R. H. Umboh, ${ }^{2}$ Linda W. A. Rotty $^{2}$
}

\author{
${ }^{1}$ Program Studi Pendidikan Dokter Fakultas Kedokteran Universitas Sam Ratulangi Manado \\ ${ }^{2}$ Bagian Ilmu Penyakit Dalam Fakultas Kedokteran Universitas Sam Ratulangi Manado \\ Email: fmptamboto@yahoo.co.id
}

\begin{abstract}
Chronic kidney disease (CKD) is defined as kidney damage which occured more than 3 months, with structural or functional abnormalities such as decreasing of glomerular filtration rate (GFR) $<60 \mathrm{ml} / \mathrm{min} / 1,73 \mathrm{~m}^{2}$. This kidney damage will certainly disrupt one of the kidney's functions as a producer of erythropoietin hormone which plays a role in the process of erythropoiesis. This is related to the hemoglobin levels in the erythocytes themselves. This study was aimed to determine the relationship between $\mathrm{Hb}$ level and GFR in patients with stage 3 and 4 CKD at Prof. Dr. R. D. Kandou Hospital Manado. This was an analytical and retrospective study with a cross-sectional design using medical record of patient with stage 3 and 4 CKD at Prof. Dr. R. D. Kandou Hospital from January 2017 to December 2018 as secondary data. The results showed that there were 50 patients with stage 3 and 4 CKD who met the inclusion criteria of 57 existing patients. The Pearson correlation test obtained a pvalue of 0.023 and an $r$ value of 0.32 for the relationship between Hb level and GFR. In conclusion, there was a significant relationship between $\mathrm{Hb}$ level and GFR in patients with stage 3 and 4 CKD at Prof. Dr. R. D. Kandou Manado from January 2017 to December 2018.
\end{abstract} Keywords: CKD, eGFR, hemoglobin level

\begin{abstract}
Abstrak: Penyakit ginjal kronik (PGK) ditandai dengan adanya kerusakan ginjal yang terjadi lebih dari 3 bulan, berupa kelainan struktural atau fungsional seperti menurunnya laju filtrasi glomeurulus (LFG) $<60 \mathrm{ml} / \mathrm{menit} / 1,73 \mathrm{~m}^{2}$. Kerusakan ginjal pada PGK akan mengganggu fungsi ginjal sebagai penghasil hormon eritropoietin yang berperan dalam eritropoiesis yang berhubungan dengan kadar hemoglobin $(\mathrm{Hb})$ dalam eritrosit. Penelitian ini bertujuan untuk mengetahui hubungan antara kadar $\mathrm{Hb}$ dan LFG pada pasien PGK stadium 3 dan 4 di RSUP Prof. Dr. R. D. Kandou Manado. Jenis penelitian ialah analitik retrospektif dengan desain potong lintang menggunakan catatan rekam medik pasien PGK stadium 3 dan 4 di RSUP Prof. Dr. R. D. Kandou Manado periode Januari 2017-Desember 2018 sebagai data sekunder. Hasil penelitian mendapatkan 50 pasien PGK stadium 3 dan 4 yang memenuhi kriteria inklusi dari 57 pasien yang ada. Hasil uji korelasi Pearson mendapatkan nilai $\mathrm{p}=0,023$ dan $\mathrm{r}=0,320$ untuk hubungan antara kadar $\mathrm{Hb}$ dengan LFG. Simpulan penelitian ini ialah terdapat hubungan bermakna antara kadar Hb dengan LFG pada pasien PGK stadium 3 dan 4 di RSUP Prof. Dr. R. D. Kandou Manado periode Januari 2017-Desember 2018.
\end{abstract}

Kata kunci: PGK, LFG, kadar hemoglobin

\section{PENDAHULUAN}

Penyakit ginjal kronik (PGK) merupakan suatu masalah kesehatan masyarakat yang dapat menimbulkan dampak yang buruk seperti gagal ginjal, penyakit kardio- vaskuler dan bahkan kematian dini. ${ }^{1}$ Penyakit ginjal kronik adalah suatu proses patofisiologis dengan etiologi yang beragam, mengakibatkan penurunan fungsi ginjal yang progresif, dan umumnya ber- 
akhir dengan gagal ginjal. Penyakit ini ditandai dengan adanya kerusakan ginjal yang terjadi lebih dari 3 bulan, berupa kelainan struktural atau fungsional, dengan atau tanpa penurunan laju filtrasi glomerulus, dengan manifestasi kelainan patologis, terdapat tanda kelainan ginjal termasuk kelainan dalam komposisi darah atau urin, atau kelainan dalam tes pencitraan (imaging test), dan laju filtrasi glomerulus (LFG) $<60 \mathrm{ml} / \mathrm{menit} / 1,73 \mathrm{~m}^{2}$ selama $3 \mathrm{bu}-$ lan, dengan atau tanpa kerusakan ginjal. ${ }^{2}$

Penelitian yang dilakukan oleh The Global Burden of Disease (GBD) pada tahun 2010 menunjukkan bahwa terdapat sekitar 2,3-7,1 juta orang dengan penyakit ginjal stadium akhir meninggal tanpa dilakukan dialisi, dan pada tahun 2015, terdapat 1,2 juta orang yang meninggal karena PGK, terdapat peningkatan sebesar 32\% sejak tahun 2005. Secara umum, diperkirakan terdapat 5-10 juta orang yang meninggal setiap tahunnya karena penyakit ginjal. ${ }^{3}$ Amerika Serikat menjadi salah satu negara dengan peringkat yang tinggi di dunia karena prevalensi kasus PGK yang pada tahun 2016 naik menjadi 124.675 kasus dari tahun sebelumnya yang berjumlah 124.111 kasus. Prevalensi PGK di Amerika Serikat meningkat $20-25 \%$ per tahunnya, adapun di Australia, Eropa dan Jepang 6-11\% per tahunnya. ${ }^{4}$ Di Indonesia sendiri, dalam hasil riset kesehatan dasar (Riskesdas) tahun 2018 prevalensi PGK di Indonesia sebesar 3,8\%. Data ini menunjukkan peningkatan dari data sebelumnya yaitu $2 \%$ pada tahun 2017 . Terdapat 70.000 penderita PGK di Indonesia dan akan meningkat sekitar $10 \%$ setiap tahunnya menurut data dari Persatuan Nefrologi Indonesia (PERNEFRI) dan prevalensi PGK tertinggi Indonesia terdapat di Provinsi Kalimantan Utara sebesar 6,4\% dan Provinsi Sulawesi Utara berada di peringkat $3 .^{5}$

Pengelompokkan atau klasifikasi pada pasien dengan PGK dibuat berdasarkan derajat penyakitnya. Klasifikasi PGK dibagi menjadi 5 derajat dengan cara mengukur kadar laju filtrasi glomerulus (LFG). Derajat 1 merupakan keadaan dimana pasien memiliki kerusakan ginjal dengan LFG yang masih normal atau meningkat dengan kadar LFG $\geq 90 \mathrm{ml} /$ menit. Derajat 2 merupakan keadaan dimana pasien memiliki kerusakan ginjal dengan kadar LFG 60-89 $\mathrm{ml} /$ menit. Derajat 3 merupakan keadaan dimana pasien memiliki kerusakan ginjal dan dibagi atas derajat 3a dengan kadar LFG $45-59 \mathrm{ml} / \mathrm{menit}$ dan derajat $3 \mathrm{~b}$ dengan kadar LFG 30-44 $\mathrm{ml} / \mathrm{menit}$. Derajat 4 merupakan keadaan dimana pasien memiliki kerusakan ginjal dengan kadar LFG 15$29 \mathrm{ml} /$ menit. Derajat 5 merupakan keadaan dimana pasien memiliki kegagalan fungsi ginjal atau disebut dengan gagal ginjal dengan kadar LFG $<15 \mathrm{ml} /$ menit. $^{2,6}$

Kerusakan ginjal yang dialami pasien dengan PGK tentunya akan mengganggu salah satu fungsi ginjal yaitu sebagai penghasil hormon eritropoietin yang berperan dalam pembentukan eritrosit dalam proses eritropoiesis. Hal ini memungkinkan terganggunya juga fungsi dari eritrosit sendiri sebagai penyalur oksigen ke jaringan-jaringan yang ada di tubuh, dimana hal ini berhubungan dengan kadar hemoglobin yang terkandung dalam eritrosit itu sendiri.?

Hemoglobin ( $\mathrm{Hb})$ merupakan suatu protein tetramerik, eritrosit yang mengikat molekul bukan protein yaitu senyawa porfirin besi disebut dengan heme. Hemoglobin mempunyai dua fungsi pengangkutan penting dalam tubuh manusia, yakni pengangkutan oksigen dari paru-paru ke jaringan perifer dan pengangkutan karbondioksida dari jaringan perifer ke paru-paru. Ketika kadar hemoglobin mengalami penurunan maka dapat terjadi anemia yaitu keadaan dimana kurangnya kadar eritrosit dalam tubuh manusia. ${ }^{8}$ Dalam mengatasi anemia yang terjadi pada pasien PGK, maka dapat diberikan intervensi berupa pemberian suplementasi besi, terapi Erythropoietin Stimulating Agent (ESA), transfusi darah maupun hemodialisis (khusus stadium 5). Intervensi ini bertujuan untuk mengembalikan kadar hemoglobin pada pasien PGK yang mengalami anemia. ${ }^{9}$

Berdasarkan latar belakang yang telah diuraikan, penulis merasa tertarik untuk mengetahui gambaran dan hubungan antara 
kadar $\mathrm{Hb}$ dan LFG pada pasien PGK stadium 3 dan 4 di RSUP Prof. Dr. R. D. Kandou Manado periode Januari 2017 Desember 2018.

\section{METODE PENELITIAN}

Penelitian ini menggunakan catatan rekam medik pasien PGK stadium 3 dan 4 di RSUP Prof. Dr. R. D. Kandou Manado periode Januari 2017-Desember 2018. Jenis penelitian ialah analitik retrospektif dengan desain potong lintang.

Pengambilan sampel penelitian ini menggunakan metode consecutive sampling. Kriteria inklusi yaitu pasien PGK stadium 3 dan 4 yang memiliki data rekam medik dengan hasil pemeriksaan penunjang berupa kadar $\mathrm{Hb}$ dan LFG yang lengkap, sedangkan kriteria eksklusi yaitu pasien PGK yang sudah melakukan tindakan intervensi berupa suplementasi besi, ESA, dan transfusi darah serta pasien PGK yang tidak memiliki data rekam medik dengan hasil pemeriksaan penunjang lengkap. Besaran sampel penelitian ialah 50 pasien menggunakan rumus korelatif. Variabel penelitian ialah kadar $\mathrm{Hb}$ dan LFG.

Penelitian ini telah mendapat persetujuan dari Komisi Etik Penelitian Kesehatan RSUP Prof. Dr. R. D. Kandou Manado, dengan nomor keterangan layak etik yaitu No. 064/EC/KEPK-KANDOU/X/2019.

\section{HASIL PENELITIAN}

Berdasarkan penelitian yang dilakukan di RSUP Prof. Dr. R. D. Kandou Manado periode Januari 2017 sampai Desember 2018 terdapat 57 pasien PGK stadium 3 dan 4. Data rekam medik yang memenuhi kriteria inklusi sebanyak 50 data dan 7 data yang lain dieksklusikan karena datanya tidak lengkap. Dari 50 data yang ada terdapat $32(64 \%)$ pasien laki-laki dan 18
(36\%) pasien perempuan.

Tabel 1 memperlihatkan uji deskriptif dan uji normalitas Kolmogorov-Smirnov untuk menilai distribusi data. Hasil pendistribusian data yang didapatkan pada variabel usia $p=0,200$, variabel kreatinin $\mathrm{p}=0,200$, variabel LFG $\mathrm{p}=0,200$, dan pada variabel hemoglobin $p=0,200$ (nilai $p>0,05$ ) sehingga dapat disimpulkan bahwa variabel usia, kreatinin, hemoglobin dan LFG memiliki data dengan distribusi normal. Usia pasien terendah yaitu 29 tahun dan tertinggi yaitu 77 tahun dengan rerata 58,46 tahun. Kadar kreatinin terendah berada pada nilai $1,70 \mathrm{mg} / \mathrm{dL}$ dan tertinggi pada nilai $3,90 \mathrm{mg} / \mathrm{dL}$ dengan nilai rerata 2,68 $\mathrm{mg} / \mathrm{dL}$. Nilai LFG terendah berada pada 15 $\mathrm{ml} / \mathrm{mnt} / 1,73 \mathrm{~m}^{2}$ dan tertinggi pada 37 $\mathrm{ml} / \mathrm{mnt} / 1,73 \mathrm{~m}^{2}$ dengan nilai rerata 24,34 $\mathrm{ml} / \mathrm{mnt} / 1,73 \mathrm{~m}^{2}$. Kadar hemoglobin terendah berada pada nilai $5,70 \mathrm{gr} / \mathrm{dL}$ dan tertinggi pada nilai 13,90 gr/dL dengan nilai rerata pada nilai $10,13 \mathrm{gr} / \mathrm{dL}$.

Gambar 1 memperlihatkan diagram sebar kadar Hb dan LFG pada pasien PGK stadium 3 dan 4 . Terdapat hubungan linier positif yang berarti semakin rendah LFG maka kadar $\mathrm{Hb}$ akan semakin rendah.

Pada penelitian ini digunakan uji korelasi Pearson terhadap hubungan antara kadar $\mathrm{Hb}$ dan LFG karena setelah dilakukan uji normalitas, variabel yang ada memiliki distribusi data normal. Hasil uji korelasi Pearson memperoleh nilai $\mathrm{p}=0,027$ $(\mathrm{p}<0,05)$ dan nilai $\mathrm{r}=0,312$ yang menunjukkan terdapatnya hubungan bermakna antara kadar $\mathrm{Hb}$ dan LFG. Nilai positif pada $\mathrm{r}$ memiliki makna terdapat korelasi positif yang berarti jika LFG menurun maka kadar $\mathrm{Hb}$ juga akan menurun, begitu juga jika LFG meningkat maka kadar $\mathrm{Hb}$ akan meningkat.

Tabel 1. Deskripsi variabel penelitian

\begin{tabular}{lccccc}
\hline \multicolumn{1}{c}{ Variabel } & n & Min & Maks & Rerata & Distribusi \\
\hline Usia (tahun) & 50 & 29 & 77 & 58,46 & 0,200 \\
Kreatinin $(\mathrm{mg} / \mathrm{dL})$ & 50 & 1,70 & 3,90 & 2,68 & 0,200 \\
LFG $\left(\mathrm{ml} / \mathrm{mnt} / 1,73 \mathrm{~m}^{2}\right)$ & 50 & 15 & 37 & 24,34 & 0,200 \\
Hemoglobin $(\mathrm{gr} / \mathrm{dL})$ & 50 & 5,70 & 13,90 & 10,13 & 0,200 \\
\hline
\end{tabular}




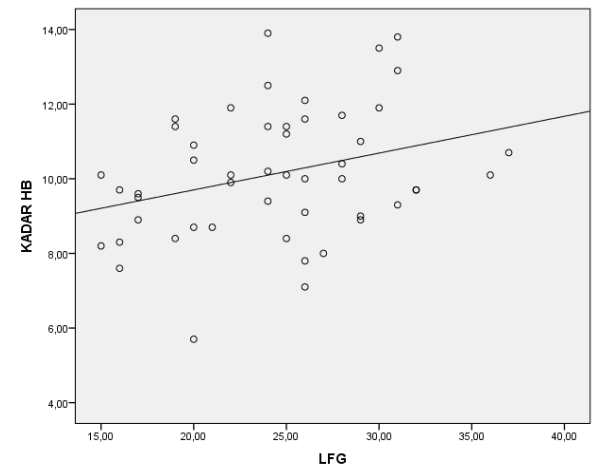

Gambar 1. Diagram sebar kadar Hb dan LFG

\section{BAHASAN}

Penelitian ini menggunakan data rekam medik pasien dengan diagnosis PGK stadium 3 dan 4 yang memiliki hasil pemeriksaan laboratorium kadar $\mathrm{Hb}$ dan LFG di RSUP Prof. Dr. R. D. Kandou Manado periode Januari 2017 s/d Desember 2018. Terdapat 57 data selama periode tersebut namun hanya 50 data yang memenuhi kriteria inklusi, sedangkan 7 data dieksklusi karena tidak memiliki hasil laboratorium kadar $\mathrm{Hb}$ dan kreatinin serta sudah melakukan tindakan intervensi berupa suplementasi besi, erythropoietin stimulating agent (ESA), dan transfusi darah.

Pada penelitian ini variabel yang diteliti ialah kadar $\mathrm{Hb}$ dan LFG. Berdasarkan hasil analisis bivariat menggunakan uji korelasi Pearson antara kadar $\mathrm{Hb}$ dan LFG didapatkan adanya hubungan bermakna dengan nilai $\mathrm{p}=0,027$ dan menunjukkan korelasi positif dengan nilai $r=0,312$. Hubungan bermakna antara LFG dan $\mathrm{Hb}$ ini juga dilaporkan oleh Hsu et $\mathrm{al}^{10}$ yang menggunakan data NHANES III (The Third National Health and Nutrition Examination) sebanyak 15.971 data (7.465 laki-laki dan 8.506 perempuan). Pada penelitian tersebut didapatkan bahwa kadar $\mathrm{Hb}$ pada laki-laki secara bermakna mulai turun (sekitar 1,4 gr/dL) saat LFG $<70$ $\mathrm{ml} / \mathrm{mnt} / 1,73 \mathrm{~m}^{2}(\mathrm{p}=0,01$ untuk LFG $50-60$ $\mathrm{ml} / \mathrm{mnt} / 1,73 \mathrm{~m}^{2} ; \mathrm{p}=0,00$ untuk LFG $40-50$ $\mathrm{ml} / \mathrm{mnt} / 1,73 \mathrm{~m}^{2}$, LFG $30-40 \mathrm{ml} / \mathrm{mnt} / 1,73 \mathrm{~m}^{2}$, LFG $20-30 \mathrm{ml} / \mathrm{mnt} / 1,73 \mathrm{~m}^{2}$, dan $\mathrm{LFG} \leq 20$ $\mathrm{ml} / \mathrm{mnt} / 1,73 \mathrm{~m}^{2}$ ), sedangkan pada perempuan, Hsu et $\mathrm{al}^{10}$ mendapatkan penurunan kadar $\mathrm{Hb}$ yang lebih lambat (sekitar 1 $\mathrm{gr} / \mathrm{dL}$ ), yaitu mulai $\mathrm{LFG}<50 \mathrm{ml} / \mathrm{mnt} /$
$1,73 \mathrm{~m}^{2}$ ( $\mathrm{p}=0,01$ untuk LFG $40-50 \mathrm{ml} / \mathrm{mnt} /$ $1,73 \mathrm{~m}^{2}, \mathrm{p}=0,00$ untuk LFG $30-40 \mathrm{ml} / \mathrm{mnt} /$ $1,73 \mathrm{~m}^{2}$, LFG $20-30 \mathrm{ml} / \mathrm{mnt} / 1,73 \mathrm{~m}^{2}$, dan LFG $\leq 20 \mathrm{ml} / \mathrm{mnt} / 1,73 \mathrm{~m}^{2}$ ). Penelitian yang dilakukan oleh McClellan et al ${ }^{11}$ mendapatkan bahwa penurunan kadar $\mathrm{Hb}$ berhubungan kuat dengan menurunnya LFG. Persentase $\mathrm{Hb}>12 \mathrm{gr} / \mathrm{dL}$ meningkat dari 26,7\% menjadi $75,5 \%$ ketika LFG turun dari 60 menjadi $15 \mathrm{ml} / \mathrm{mnt} / 1,73 \mathrm{~m}^{2}$. Menurunnya kadar $\mathrm{Hb}$ ditemukan pada $47,7 \%$ dari 5.222 pasien PGK predialisis dan menurunnya fungsi ginjal yang ditandai dengan menurunnya LFG dapat memicu menurunnya kadar $\mathrm{Hb} .{ }^{11}$

Hasil penelitian lainnya yang mendukung hal ini ialah penelitian yang dilakukan oleh Suega $^{12}$ pada 80 pasien PGK predialisis di RSUP Sanglah Denpasar, Bali tahun 2010 yang melaporkan bahwa terdapat $41 \%$ pasien PGK predialisis yang memiliki penurunan kadar $\mathrm{Hb}$. Penelitian tersebut dilakukan menggunakan uji korelasi Pearson terhadap hubungan antara kadar $\mathrm{Hb}$ dan LFG dan didapatkan hubungan positif yang bermakna dengan nilai $\mathrm{p}=0,00$ dan $\mathrm{r}=0,76$ yang berarti penurunan kadar $\mathrm{Hb}$ memiliki hubungan dengan menurunnya LFG. Hal ini juga sejalan dengan penelitian yang dilakukan oleh Apriani ${ }^{13}$ pada 60 pasien PGK dengan menggunakan data rekam medik di Instalasi Rekam Medik Rumah Sakit Umum Daerah dr. Sayyidiman Magetan tahun 2013, dimana terdapat korelasi positif antara penurunan kadar $\mathrm{Hb}$ dan LFG pada pasien dengan kadar LFG <60 $\mathrm{ml} / \mathrm{mnt} / 1,73 \mathrm{~m}^{2}$ dengan nilai $\mathrm{p}=0,019$ dan $\mathrm{r}=0,302$.

\section{SIMPULAN}

Terdapat hubungan positif bermakna antara kadar $\mathrm{Hb}$ dengan LFG pada pasien PGK stadium 3 dan 4 di RSUP Prof. Dr. R. D. Kandou Manado periode Januari 2017Desember 2018.

Untuk penelitian selanjutnya diharapkan dapat mengambil data primer yang merupakan hasil wawancara langsung dengan pasien yang bersangkutan, agar informasi yang didapatkan lebih jelas dan akurat karena akan sangat memengaruhi hasil 
penelitian. Perlu dipertimbangkan dan dicari hal-hal yang dapat membuat kadar $\mathrm{Hb}$ pasien menurun seperti riwayat perdarahan atau penyakit-penyakit lain yang diderita pasien sebelumnya, karena dapat menjadi perancu pada hasil yang ada. Oleh karena itu, hal-hal tersebut harus dimasukkan di dalam kriteria eksklusi.

\section{Konflik Kepentingan}

Penulis menyatakan tidak terdapat konflik kepentingan dalam studi ini.

\section{DAFTAR PUSTAKA}

1. Levey AS, Eckardt KU, Tsukamoto Y, Levin A, Coresh J, Rossert J, et al. Definiton and classification of chronic kidney disease : A position statement from disease: Improving Global Outcomes (KDIGO). Kidney International. 2005; 67:2089-100.

2. Suwitra K. Penyakit ginjal kronik. In: Setiati S, Alwi I, Sudoyo AW, Simadibrata M, Setiyohadi B, Syam AF, editors. Buku Ajar Ilmu Penyakit Dalam (6th ed). Jakarta: InternaPublishing, 2014; p. 2161.

3. Luyckx VA, Tonelli B, Stanifer JW. The global burden of kidney disease and the sustainable development goals. Bulletin of the World Health Organization. 2018;96:414-22.

4. Saran R, Robinson B, Abbot KC, Agodoa LYC, Gresham JB, Balkrishnan R, et al. US Renal Data System 2018 Annual Data Report: Epidemiology of Kidney Disease in the United States. National Kidney Foundation. 2019;73:A7-A8.

5. Kemenkes RI. Riset Kesehatan Dasar (Riskesdas). Jakarta: Balitbang Kemen kes RI, 2018.
6. Hogg JR, Furth S, Lemley KV, Portman R, Schwartz GJ, Coresh J, et al. National Kidney Foundation's disease outcomes quality initiative clinical practice guidelines for chronic kidney disease in children and adolescents: evaluation, classification, and stratification. Pediatrics. 2003;11(6):1416-9.

7. Goldman L, Schafer Al. Goldman-Cecil Medicine E-book. Elsevier Health Sciences, 2015; p. 1059-68.

8. Kenelly PJ, Rohm KH. Protein: Mioglobin dan hemoglobin. In: Murray RK, Granner DK, Rodwell VW, editors. Biokimia Harper (27th ed). Pendit BU, alih bahasa Indonesia. Wulandari N, editor edisi bahasa Indonesia. Jakarta: EGC; 29. P. 44-52.

9. KDIGO Clinical practice guideline for anemia in chronic kidney disease. Kidney Int Suppl 2012;2:283-308.

10. Hsu C, Mcculloch CE, Curhan GC. Epidemiology of anemia associated with chronic renal insuficiency among adults in the Unites States: results from the third national health and nutrition examination survey. J Am Soc Nephrol. 2002;13:504-10.

11. Mcclellan WM, Aronoff SL, Bolton WK. The prevalence of anemia in patients with chronic kidney disease. Curr Med Res Opin. 2004;20:1501-10.

12. Suega K. Hubungan antara beberapa parameter anemi dan laju filtrasi glomerulus pada penyakit ginjal kronik pradialisis. Jurnal Penyakit Dalam. 2012 Sep:140.

13. Apriani Y. Korelasi antara penurunan laju filtrasi glomerulus dengan beratnya anemia pada penyakit ginjal kronik di RSUD DR. Sayyidiman Magetan [Disertasi]. Surakarta: Universitas Muhammadiyah Surakarta; 2014. 